\title{
Belphégor
}

\section{The Poet of the Pulps : Ray Bradbury and the Struggle for Prestige in Postwar Science Fiction}

\section{Anthony Enns}

\section{(2) OpenEdition}

1 Journals

\section{Electronic version}

URL: http://journals.openedition.org/belphegor/615

DOI: 10.4000/belphegor.615

ISSN: 1499-7185

Publisher

LPCM

\section{Electronic reference}

Anthony Enns, «The Poet of the Pulps : Ray Bradbury and the Struggle for Prestige in Postwar Science Fiction », Belphégor [Online], 13-1 | 2015, Online since 01 June 2015, connection on 21 December 2020. URL : http://journals.openedition.org/belphegor/615 ; DOI : https://doi.org/10.4000/belphegor. 615

This text was automatically generated on 21 December 2020.



Belphégor est mis à disposition selon les termes de la Licence Creative Commons Attribution - Pas d'Utilisation Commerciale - Pas de Modification 4.0 International. 


\title{
The Poet of the Pulps : Ray Bradbury and the Struggle for Prestige in Postwar Science Fiction
}

\author{
Anthony Enns
}

1 From the 1920 s to the 1940 s American science fiction could only be found in pulp magazines like Amazing Stories (1926-2005), Science Wonder Stories (1929-1955), Astounding Stories of Super-Science (1930-1955), Marvel Science Stories (1938-1952), Planet Stories (1939-1955), and Super Science Stories (1940-1951). This period later came to be known as the "pulp era" of science fiction due to the fact that it was virtually non-existent in any other form. The term "pulp" was derived from the wood-pulp paper on which these magazines were printed, which was chemically untreated and therefore rough, acidic, and fragile. The magazines were printed on wood-pulp paper because they were designed to be produced cheaply, consumed quickly, and discarded immediately. The inferior quality of the paper stock also reflected the low cultural status of the magazines, as their disposability encouraged readers to perceive the content as trivial and inconsequential. Science fiction was thus seen at the time as part of the inexorable spread of mass culture, which seemed to pose a threat to the nation's cultural and moral standards. In 1939, for example, American historian Bernard DeVoto described science fiction as "besotted nonsense," and he noted that most science fiction stories were no different from those found in "cowboy pulps," but "rephrased in terms of death rays, with heroic earthmen overcoming malign Venusians on the last page" (446). Even as late as 1953, when the "pulp era" was largely over, critics like Dwight Macdonald still associated the genre with the puerile sensationalism of pulp fiction :

[T] here are vast lower strata of science-fiction where the marvellous is untrammelled by the limits of knowledge. To the masses, science is the modern arcanum arcanorum, at once the supreme mystery and the philosopher's stone that explains the mystery.... But science itself is not understood, therefore not mastered, therefore terrifying because of its very power. Taken this way, as the supreme mystery, science becomes the stock in trade of the "horror" pulp magazines and 
comics and movies. It has got to the point, indeed, that if one sees a laboratory in a movie, one shudders, and the white coat of the scientist is as blood-chilling a sight as Count Dracula's black cloak. (12-13)

2 Science fiction was thus associated with other forms of mass entertainment, like comics and movies, which reinforced and perpetuated the ignorance of the masses. Librarians, parent-teacher associations, and religious groups similarly regarded these publications as a threat to the nation's youth by inhibiting the development of literacy and preventing young readers from appreciating "serious" works of literature.

Despite these negative evaluations of the genre (or perhaps because of them), science fiction gradually expanded into the literary market through paperback and hardcover novels. These new formats fundamentally altered the status of the genre, as they appealed to a wider readership and were more often reviewed in mainstream literary publications. Over time, science fiction gradually acquired a level of cultural prestige that was never afforded to pulp magazines, and this shift was the result of a change not in the content but rather in the material qualities of science fiction texts. The early 1950 s was therefore a particularly significant period in the history of American science fiction publishing, as it witnessed a dramatic transformation in the production, distribution, and reception of the genre, and this transformation reveals the inherent connections between distinctions of taste and the materiality of written texts.

In order to examine this relationship between prestige and materiality more closely, the following essay will focus on the publication history of Ray Bradbury's 1953 science fiction novel Fahrenheit 451. The history of this novel vividly illustrates the changing status of the genre not only because it was one of the first magazine stories to be expanded and republished as a novel, but also because it was one of the first science fiction novels to achieve significant recognition among mainstream literary critics. This achievement was largely the result of a new publishing strategy, as it was among the first novels that Ballantine Books published simultaneously in both paperback and hardcover editions. The struggle for prestige is also mirrored within the narrative itself, as it focuses on how mass media contribute to a frightening degradation of culture, just as many critics feared at the time. One possible implication of the novel's success, therefore, is that science fiction needed to distance itself from its lowbrow origins and embrace the values of "serious" literature in order to achieve a degree of cultural respectability - a respectability that was reflected in and depended on the materiality of the book form. This claim is somewhat problematic, however, as the novel was published in several different magazine and book formats, and this publishing strategy was designed to appeal to a wide range of taste cultures, which complicates the notion that it was simply an elitist text that critiques the rise of mass entertainment. Bradbury was also one of the most famous pulp writers at the time, and in the early 1950s he was actively involved in virtually all aspects of the entertainment industry, including comic books, radio, television, and film. Furthermore, Bradbury's depiction of book burning, which is the primary focus of the narrative, was directly inspired by the morality campaigns of the late 1940s and early 1950s, which led to the demise of science fiction comics. By simultaneously appearing in multiple print formats and by challenging mid-twentiethcentury morality campaigns, Fahrenheit 451 clearly illustrates how competition between media represented an ongoing struggle for power and prestige.

5 Mike Ashley's detailed history of American science fiction magazines identifies the early 1950s as a pivotal moment in the history of science fiction publishing due to the sudden 
collapse of the pulp market and the rise of a new kind of mass market publication known as the "digest" magazine. The first digest magazine, The Magazine of Fantasy, was published in 1949, and Ashley describes it as "a slick in book format," as its smaller size, high-quality paper stock, use of single columns, and absence of interior artwork made it look more like a book than a pulp (22). It was also placed next to mass market books on newsstands, while pulps were increasingly pushed to the side, which had the "benefit of making the magazine seem more grown-up and more literary" (46). Beginning with the second issue, the magazine was retitled The Magazine of Fantasy and Science Fiction and the covers were designed by George Salter. Salter had never worked on pulps, but he had developed an international reputation for his paperback covers, which remained closer to the style of highbrow publishing graphics. As chairman of the Book Jacket Designers Guild, Salter was also the industry's leading advocate for high-quality book jackets, and he was firmly committed to the idea that low artistic standards would "trivialize literature and debase public taste" (Hansen 37). Publishers thus "relied upon Salter's image to lend intellectual respectability to their products," and his involvement with Mercury Publications gave the company "a cachet no other publisher could claim" (Hansen 43). Ashley similarly argues that Salter's designs gave The Magazine of Fantasy and Science Fiction "a more sophisticated book aura" (22), which made "the whole field of science fiction look good and feel good" (24).

The second digest magazine, Galaxy Science Fiction, appeared the following year, and it similarly distanced itself from the sensationalism of pulp magazines through the use of an understated cover, designed by artist David Stone, which featured an asteroid on the bottom right and a plain white border along the top and left side. In his editorial for the first issue, Horace Gold proudly stated that "GALAXY Science Fiction intends to be a mature magazine for mature readers," and he explained the importance of the cover in conveying this sense of maturity: "Long a science fiction fan, Stone...was weary of tearing covers off magazines to avoid embarrassment. His cover, he resolved, would not have to be hidden.... Having suffered thus ourselves, we agreed, and no reader will be ashamed to carry GALAXY" (2). In addition to emphasizing the importance of the cover art, Gold also stressed the quality of the cover stock: "GALAXY Science Fiction is dressed in Champion Kromekote, an expensive and unusual coated paper...[which is] an important quality to readers who dislike having to wash after reading a magazine" (3). While pulp readers were forced to wash due to the fact that the ink would rub off on their hands, the connotations of this phrase also implied that there was something inherently dirty or shameful about reading such magazines. The material properties of the digest thus provided what Gold described as "a beautiful and dignified vehicle for science fiction" (3), which signaled its departure from the genre's pulp origins. As Ashley points out, "the idea was to have a magazine that you were not embarrassed to hold," and Stone's cover represented "a statement about quality and style, even though in itself it was nothing special" (24). Like The Magazine of Fantasy and Science Fiction, therefore, Galaxy sought to incorporate material and stylistic innovations that served to distance digest magazines from pulp magazines. These innovations also signaled a shift in the genre's cultural status, as they "made the digest form synonymous with respectability" (32). Ashley notes, for example, that the rise of the digests initiated a publishing war with the pulps, which became increasingly apparent in 1952 when four new digests and three new pulps appeared on the market: "When I report that between them the four digest magazines would eventually notch up a total of 400 issues, while the three pulp titles managed only 13 issues in total, the result of the war becomes only too obvious" (43). Ashley also 
emphasizes that the collapse of the pulps was due not to the poor quality of their content, as "some...remained excellent to the end," but rather to the material form of the digests, which connoted a higher level of cultural prestige (70). Attebery also notes that Galaxy "was, in essence, a monthly series of original anthologies, and it demonstrated to the publishing world the viability of such anthologies, and of science fiction as a category for book publication" (46). Digests thus transformed the public perception of the genre, as science fiction "ceased to be identified primarily as a magazine form" (46).

Other signs of this cultural shift include the appearance of science fiction stories in mainstream magazines like Playboy, which first appeared in 1953. Hugh Hefner had been an avid reader of pulp science fiction in the 1940s, and he explicitly sought to grant the genre a more elevated status. In his preface to The Playboy Book of Science Fiction and Fantasy, editor Ray Russell even claims that Playboy single-handedly rescued the genre from its association with pulp magazines :

Prior to 1954, science fiction and fantasy were almost totally restricted to specialized, small-circulation pulp magazines.... What happened in 1954 to change all this? Playboy happened. For the first time, a major periodical, a "slick" magazine, began to consistently publish extrapolative stories, realistically inexplicable tales the entire spectrum of science fiction and fantasy. And, also for the first time, writers of this fiction found themselves in receipt of certain delightful, desirable things they had long lacked : wide recognition and money. (vii)

Ashley similarly argues that Playboy's broad readership and high payment rates provided "an opportunity for science fiction to become more widely appreciated and gave sf writers a market that was intermediate between the pulps...and the more refined slicks" (70).

9 The paperback market similarly represented a middle ground between the lowbrow realm of the pulps and the highbrow realm of "serious" literature. The first paperback science fiction anthology was The Pocket Book of Science-Fiction, published by Pocket Books in 1943. This anthology reprinted stories from various pulps, although Ashley notes that it appealed to readers who "would never have sanctioned the low-grade pulps," and "many who read the stories in the anthologies had no idea they came from the pulp magazines" (197). Beginning in 1950 companies like Hillman and Avon also began republishing pulp science fiction stories in digest-form paperbacks, and Doubleday even began publishing original science fiction novels in hardcover editions. Both of these formats offered higher payment rates and a broader readership, yet they clearly differed in terms of their cultural prestige, as paperbacks were more closely associated with profit-driven modes of mass production. As Cecil Hemley argued in his 1954 article on "The Problem of the Paper-backs," the paperback publisher "must fall back on genres" in order to maximize profits, and paperback editions of "serious" literature are diluted when placed next to these lowbrow texts (141). While paperbacks were thus seen as more respectable than pulps, they were still viewed with a certain degree of suspicion among literary critics, who expressed concern that science fiction paperbacks would be perceived as culturally equivalent to paperback editions of "serious" literature.

One of the most popular pulp authors at this time was Ray Bradbury, whose stories regularly appeared in such magazines as Thrilling Wonder Stories, Planet Stories, and Super Science Stories. In 1950 Doubleday published a hardcover collection of Bradbury's pulp stories, The Martian Chronicles, which received a favorable review from Christopher Isherwood. In his review, Isherwood attempted to distance Bradbury from other pulp authors by arguing that his stories were not science fiction but rather "tales of the 
grotesque and arabesque," thus placing him firmly in the tradition of Edgar Allan Poe: "Poe's name comes up, almost inevitably, in any discussion of Mr. Bradbury's work; not because Mr. Bradbury is an imitator (though he is certainly a disciple) but because he already deserves to be measured against the greatest master of his particular genre" (56). David Mogen describes this review as the single greatest achievement of Bradbury's career (15), and Jonathan Eller similarly describes it as a "critical breakthrough" that brought Bradbury's work "more fully into mainstream literary appreciation" (211). Evan Brier also points out that Isherwood's endorsement "helped Bradbury make inroads into the literary mainstream" (62), as his stories immediately began to appear in "slick" magazines like Collier's, Harper's, and The Saturday Evening Post. Bradbury sought to publish his work in these magazines because they offered not only higher payment rates, but also mainstream literary recognition. He openly admitted in interviews, for example, that he was acutely aware of the stigma attached to science fiction at this time: "[I]f you went to party and told somebody you were a science-fiction writer you would be insulted" (Weller). He even began publishing stories in academic publications like Epoch, Cornell University's literary magazine, and Shenandoah, the literary magazine of Washington and Lee University, despite their relatively low payments rates. Bradbury's ambiguous literary status became particularly evident when Time magazine referred to him as the "poet of the pulps" ("Poet of the Pulps" 116). The notion of Bradbury as a "poet" was clearly intended to elevate his work above that of other science fiction writers, yet by positioning him firmly in the realm of the "pulps" this somewhat backhanded compliment also served to limit his potential sphere of influence.

11 As soon as Bradbury got his first taste of mainstream literary recognition, he began writing what would become his most famous story: "The Fireman." The story describes a dystopian future in which mass culture has eclipsed high culture and firemen do not put out fires but rather burn books. The protagonist is a fireman named Montag, who gradually learns the value of literature and joins a secret society of intellectuals in the wilderness shortly before the ignorant masses are destroyed in a war caused by their own addiction to escapist entertainment. The story thus explicitly promoted the value of highbrow culture, and it is no surprise that it was also one of the first stories that Bradbury wrote specifically for the slicks rather than the pulps. Bradbury's agent initially submitted "The Fireman" to Esquire, Maclean's, Collier's, The Saturday Evening Post, Cosmopolitan, and Town \& Country, yet it was repeatedly rejected due to the editors' negative perceptions of the genre. As Eller notes, Maclean's "turned it down in order to avoid the perception of publishing too much science fiction" (215). Horace Gold then purchased the serial rights for Galaxy, and it appeared in the February 1951 issue without any substantive changes. "The Fireman" thus became one of the first major stories published in one of the first major science fiction digests, and it helped to solidify the reputation not only of the magazine, which sought to distance itself from the pulps, but also of the genre as a whole, as it explicitly endorsed the idea that science fiction could serve to promote rather than threaten cultural standards.

12 In August 1952 Bradbury was approached by a representative from Ballantine Books, a new company founded by Ian Ballantine, the former president of Bantam Books. Ballantine had formed this company with the intention of introducing a new business strategy that involved publishing original science fiction paperbacks, and he was looking for established authors with successful sales records. Ballantine offered Bradbury an advance as well as second-serial and anthology rights if he would expand "The Fireman" 
into a novel, which would be published simultaneously in both paperback and hardcover editions (Eller 259-260). Bradbury accepted the offer, and Ballantine published the expanded version in October 1953 under the title Fahrenheit 451 (the title refers to the temperature at which paper burns). The paperback was priced at 35 cents and the hardcover was priced at $\$ 2.50$, which was comparable to other "serious" novels. There was also a special edition of 200 signed and numbered copies bound in a chrysolite asbestos material. Not only were these editions released at the same time, but they also featured the same "burning man" image, which was drawn by artist Joseph Mugnaini, who went on to become one of Bradbury's primary illustrators. Bradbury explained that the idea for this image came from a pen-and-ink sketch he had seen in Mugnaini's studio, which depicted Don Quixote surrounded by books and wearing armor made of magazine pages (Eller 275). The image thus encapsulated the theme of "literature under siege" through its reference to the famous literary character, yet this figure was constructed from the pages of a disposable, mass-produced medium, thus serving as a reminder of the story's origin in the digest magazines. The expanded novel was also serialized in Playboy between March and May 1954. Brier explains that this publication strategy was designed to maximize both profits and prestige :

The hardcover would get the book some respectability (perhaps a place in finer bookstores and review pages).... The paperback, of course, sold on newsstands, at train stations, and in pharmacies at a low price, would generate sales. Ballantine perceived other benefits as well to this strategy: the mass production of the paperbacks would allow the hardcover to be sold at a slightly lower price, and to entice authors to publish works as original paperbacks he offered a higher royalty rate than any other company. (63)

13 The history of Fahrenheit 451 is particularly interesting, therefore, because it reflects all of the changes that were taking place in science fiction publishing at this time, as publishers were attempting to claim a new cultural terrain for science fiction that lay somewhere between the lowbrow realm of the pulps and the highbrow realm of "serious" literature.

Critics are largely divided in their interpretations of Fahrenheit 451. While some critics interpret the novel as a critique of government oppression (Mogen 105-108, Hoskinson 345-359), others interpret the novel as a critique of mass culture (McGiveron 245-256, Brier 45-73). Jack Zipes was one of the first critics to point out that the novel's critique of mass culture fundamentally contradicts its critique of totalitarianism:

[W]hile Bradbury does amply reflect the means and ways the state endeavors to manipulate and discipline its citizens in the United States, he implies that the people, i.e., the masses, have brought this upon themselves and almost deserve to be blown up so that a new breed of booklovers may begin to populate the world.... This elitist notion ultimately defeats...Bradbury's critique of...totalitarianism because he does not differentiate between social classes and their vested interests in America, nor can he explain or demonstrate from a political perspective... who profits by keeping people enthralled and unconscious of the vested power interests. (191-192)

Brier attempts to reconcile this apparent contradiction by arguing that the novel effectively blames the masses for the rise of totalitarianism. Instead of promoting the democratization of literature, therefore, the novel actually argues that "books should be left to the few" who can truly understand and appreciate them (71). While the success of the novel was largely due to the "paperback revolution," which made books cheaper and more widely available than ever before, Brier concludes that the narrative "ends by imagining the antipaperback revolution, that which occurs only by not attempting to 
distribute books to the masses, by limiting distribution of books to a degree never imagined even by the most exclusionary modernists" (71). Like "The Fireman," therefore, Fahrenheit 451 has also been read as an elitist fantasy in which the ignorance of the masses leads to their inevitable destruction and the ruling class then assumes its rightful place as the guardians of culture.

There is some truth to these arguments, as Bradbury's novel often seems to suggest that the poor quality of mass culture reflects the ignorance of the masses themselves - an idea that was endorsed by critics associated with the "culture and civilization" tradition, the Frankfurt School, and the New York intellectuals. I would add, however, that a consideration of the novel's publication history as well as the history of science fiction publishing at this time reveals additional layers of ambiguity that complicate such an interpretation. These ambiguities become evident through an examination of both the material instantiations of these texts and the representations of textual materiality within the narratives themselves. For example, critics often see "The Fireman" and Fahrenheit 451 as identical in terms of their underlying messages, yet there are significant differences between these texts that reveal a subtle shift in Bradbury's attitude toward mass culture. While the original story primarily focuses on the problems caused by the rise of mass media, including comic books, radio, and television, the expanded novel attempts to combine this media critique with a critique of middlebrow culture. The differences between these texts are also closely related to their material forms, as the story's critique of mass culture was closely related to the digest's attempts to challenge the lurid sensationalism of pulps and the novel's critique of middlebrow culture was closely related to the paperback's attempts to democratize literature. The differences between these narratives are thus directly related to the material differences between the texts themselves.

17 The story's critique of mass media is fundamentally based on the premise that mass culture naturally tends towards standardization and homogenization because it appeals to the lowest common denominator. As Leahy, Montag's boss, explains :

It started around about the Civil War, I'd say. Photography discovered. Fast printing presses coming up. Films at the early part of the $20^{\text {th }}$ Century. Radio. Television. Things began to have mass.... And because they had mass, they became simpler. Books, now. Once they appealed to various small groups of people, here and there. They could afford to be different. The world was roomy. But then the world got full of mass and elbows. Films and radios and magazines and books had to level down to a sort of paste-pudding norm. (18)

18 According to Leahy, therefore, the dystopian society depicted in the story was a direct result of the rise of new media technologies, which displaced the cultural centrality of print. Leahy also argues that the speed of these technologies inhibits concentrated thought: "The mind of man, whirling so fast under the pumping hands of publishers, publicists, ad men, broadcasters that the centrifuge throws off all ideas! He is unable to concentrate!" (19). As a result, readers gradually stopped reading: "The book buyer, bored by dishwater, his brain spinning, quit buying. Everyone but the comic publisher died a slow publishing death" (20). The rise of mass media thus led to the death of literature, and it created an environment that was hostile to the literary elite. This is perhaps most clearly seen when Leahy states that the term "intellectual" became "a swear word" (20). tradition, which was similarly based on the notion that the rise of mass media posed a 
threat to cultural standards. For example, in their 1933 book Culture and Environment: The Training of Critical Awareness, F. R. Leavis and Denys Thompson argue that mass entertainment contributes to the process of "leveling-down" due to the fact that it requires so little effort:

The great agent of...destruction has of course been the machine.... [T] he advantage it brings us in mass-production has turned out to involve standardization and leveling-down outside the realm of mere material goods. Those who in school are offered (perhaps) the beginnings of education in taste are exposed, out of school, to the competing exploitation of the cheapest emotional responses; films, newspapers, publicity...offer satisfaction at the lowest level, and inculcate the choosing of the most immediate pleasure, got with the least effort. (3-5) but his concentration is constantly disrupted by advertising messages broadcast over
loudspeakers: expressions resemble those of corpses (9). The story particularly focuses on the effects of advertising. At one point in the narrative, for example, Montag ttempts to memorize a passage from the book of Luke while riding a public "jet train,"

“Try Denham's Dentifrice tonight!" screamed the radio....

"Shut up," thought Mr. Montag in panic. "Behold, the lilies of the field -"

"Denham's Dentifrice!"

"They toil not -"

"Denham's Dentifrice!"

"Behold, the lilies of the field, shut up, let me remember!" (27)

This scene vividly illustrates how mass media promote a state of distraction that makes concentrated reading virtually impossible.

While Leavis' argument was largely based on the mass media of the 1930s, Bradbury's story was also informed by contemporary attacks on the mass media of the 1940s particularly comic books and pulp magazines. In the late 1940s there was growing concern in the U.S. that these publications were contributing to a rise in juvenile delinquency. The leading opponent of comic books was psychiatrist Fredric Wertham, who performed psychological evaluations of convicted felons for the New York Court of General Sessions. Wertham gradually became convinced that the problem of juvenile 
delinquency was directly attributable to comic books. He first presented this theory at a symposium on "The Psychopathology of Comic Books," which was organized by the Association for the Advancement of Psychotherapy in New York in March 1948. Time magazine ran a story on the symposium, and later that month an interview with Wertham was featured in Collier's magazine, which presented him as the leading spokesman in the crusade against comic books. In this interview, Wertham claimed that comic books degraded the morals of young readers by making "violence alluring and cruelty heroic" (Crist 22). Wertham supported these claims by noting that "comic book reading was a distinct influencing factor in the case of every single delinquent or disturbed child" he had studied (22). He also provided anecdotal evidence, such as a twelve-year-old boy who killed another boy because "he called me a sissy" and a brother and sister, ages eleven and eight, who stabbed a seven-year-old boy with a fountain pen in order "to see what it felt like to kill" (23). Like Leavis, therefore, Wertham argued that mass culture has a hypnotic effect that causes people to become detached from reality, and he concluded that "the time has come to legislate these books off the newsstands and out of the candy stores" (22).

In May 1948 the Saturday Review of Literature featured an edited version of Wertham's conference presentation, in which he described the crusade against comic books as a battle between concerned parents and sinister capitalists. After noting that "seventy-five percent of parents are against comic books," he added that the remaining "twenty-five percent are either indifferent or misled by propaganda and 'research"' (29). This questionable "research" was produced by the "apologists of comic books," who "function under the auspices of the comic-book business (although the public is not let in on that secret)" (29). Wertham thus implied that anyone who defended comic books was being financed by the industry, while his own research was reliable, as it was "the first carried out independently from the comic-book industry" and "the first leading to their condemnation" (29). This rhetorical strategy served not only to discredit any evidence that contradicted Wertham's claims but also to mobilize parents by describing them as the unwitting victims of "sociologists, educators, [and] psychiatrists" (29). In other words, Wertham preyed on the fears of parents by attempting to convince them that the statelicensed experts who were supposedly responsible for protecting the health and wellbeing of their children were actually agents of an industry whose sole concern was increasing profits.

26 A condensed version of Wertham's presentation appeared in the August 1948 issue of Reader's Digest, and with the help of this exposure Wertham was able to create a tremendous groundswell of support for his crusade against comic books.

By October 1948 more than fifty cities had banned comic books and more than half of state legislatures were debating bills to limit comic book sales (Jones 240). Several communities also held public book burnings. In October 1948, for example, students at Spencer Elementary School in Spencer, West Virginia, collected more than two thousand comic books, which were burned on school grounds with the assistance of parents and teachers (Hajdu 114-117). In December 1948 students at St. Patrick's Academy in Binghamton, New York, burned hundreds of comic books in the playground behind their school (Hajdu 120-126). In February 1949 a troop of girl scouts in Cape Girardeau, Missouri, collected hundreds of comic books and brought them to St. Mary's Cathedral School, where a mock trial was held, the books were found guilty of "leading young people astray," and they were then burned. Book burnings also took place at Saints Peter 
and Paul Elementary School in Auburn, New York (a small city about sixty miles northwest of Binghamton) and St. Cyril's Parish School in Chicago, Illinois (Hajdu 126-127, Wright 86). These book burnings received extensive press coverage, and the practice continued until 1954, when the Comics Code Authority was established to regulate the content of comic books.

"The Fireman" clearly reflects and reinforces Wertham's critique of comic books. In the story, comic books are the only printed material that is not burned, and their continued presence has produced a nation of juvenile delinquents. As Montag's neighbor Clarisse explains : “They kill each other. It didn't used to be that way, did it ? Children killing each other all the time? Four of my friends have been shot in the past year. I'm afraid of children" (13). The dystopian society described in the story thus represents a mirror image of the morality campaigns of the late 1940s and early 1950s: while moral crusaders burned comic books in order to prevent juvenile delinquency, Bradbury's story depicts a future in which secular crusaders burn everything except comic books and as a result every child is a juvenile delinquent. In other words, the society depicted in Bradbury's story represents the ultimate realization of the moral crusaders' worst nightmares, and it thus appeared to encourage the practice of book burnings which was designed to preserve moral and cultural standards by halting the spread of mass culture.

Bradbury's story also emphasizes the cultural importance of "serious" literature by extolling the material qualities of highbrow books. As the firemen burn a woman's book collection, for example, the narrator describes the way she touches her books before they are destroyed: "She knelt among them to touch the drenched leather, to read the gilt titles with her fingers instead of her eyes" (8). This focus on the materiality of the book is repeated later in the story when Montag delivers the last remaining Bible to Professor Faber: "It's beautiful.... There were a lot of lovely books once. Before we let them go" (28). The prestige of "serious" literature is thus embodied in the materiality of deluxe editions, such as the use of leather covers and gilt lettering. In these instances, the book effectively becomes an archeological relic whose scarcity endows it with an aura of uniqueness that distances it from industrial modes of production. This aura also explains how the book is able to assume a ritualistic function. The gesture of kneeling, for example, implies that the book has become an object of worship or adoration, as its material form is valued as much as (if not more than) its linguistic content. This emphasis on the materiality of the book thus serves to illustrate the separation between comic books and "serious" literature: while the former are cheap and disposable, the latter assume an aura of permanence, as their value appears to increase with age. It is also tempting to interpret these moments of adoration as expressions of the author's own deep and abiding love for books, which he frequently emphasized in interviews: "You have to hold [a book] in your hands and pray to it.... And it stays with you forever" (Weller).

The notion that Bradbury's story endorses the morality campaigns of the late 1940s and early 1950s may seem somewhat paradoxical, however, as the layout of the text closely resembles the style of pulp magazines. For example, the text was not only published in two columns, but it was also accompanied by copious illustrations, which was typical of pulps. The science fiction genre was also closely associated with pulps, whose status was seen as synonymous with that of comic books. Indeed, as comic books came under attack by Wertham and his followers, so too were pulps (and the science fiction genre itself) seen as being under attack, as Ashley explains : "In the eyes of the public and distributors, [pulps] were so closely linked to the comic-books that a blight on one would seriously 
affect the other - and that is what happened" (71). The material form of the text thus reflects a pulp aesthetic that was closely associated with science fiction, yet this was precisely the same aesthetic that the story appears to condemn. In other words, the visual appearance of Bradbury's story as a mass-produced and disposable commodity seems to contradict the underlying message of the narrative.

This contradiction is especially puzzling considering the fact that the principle target of the morality campaigns of the 1940s and 1950s was EC Comics, a company that published more than two dozen adaptations of Bradbury's short stories in such titles as Weird Fantasy, Weird Science, Crime Suspenstories, Tales from the Crypt, and Haunt of Fear. Bradbury's admiration for EC Comics was also revealed in a fan letter that he wrote following the publication of Joe Orlando's "Judgment Day," which appeared in Weird Fantasy \#18 (March-April 1953): "I realize you've been battling in the sea of comics to try and do better things. You have certainly succeeded in JUDGMENT DAY, which should be required reading for every man, woman, and child in the United States. You've done a splendid thing here and deserve the highest commendation" ("Cosmic Correspondence"). At the same time that Bradbury's work was being adapted for comic books, it was also being adapted for radio programs like Dimension X (May-September 1950) and Escape (June 1950) and television programs like Lights Out (July 1951), Out There (December 1951), and Suspense (February 1952). Producer John Haggott even purchased the rights to adapt five additional stories, including "The Fireman," for the second season of Out There, but the series was cancelled in 1952 before these adaptations were produced (Eller 243). That same year, producer John Houseman and director Vincente Minnelli attempted to make a film adaptation of The Martian Chronicles. While this project was never realized, producer Hal Chester succeeded in adapting Bradbury's 1951 Saturday Evening Post story "The Beast from 20,000 Fathoms," which was released by Warner Bros. in 1953. During the summer and fall of 1952 Bradbury even spent six weeks under contract at Universal Studios writing the treatment for the film It Came from Outer Space, which was also released in 1953 (Eller 266). "The Fireman" thus appeared at the same time that Bradbury's work was being adapted for comic books, radio, television, and film, and producers were eager to adapt "The Fireman" for these media as well.

This apparent paradox helps to explain the alterations that Bradbury made to the story when he expanded it into a novel. While the critique of mass culture is still evident, the novel focuses primarily on the rise of special interest groups. In the scene where Montag's boss explains the history of book burning, for example, he adds that an increase in the population resulted in the rise of vocal minority groups, which began to challenge the way they were represented in the media :

Bigger the population, the more minorities. Don't step on the toes of the dog lovers, the cat lovers, doctors, lawyers, merchants, chiefs, Mormons, Baptists, Unitarians, second-generation Chinese, Swedes, Italians, Germans, Texans, Brooklynites, Irishmen, people from Oregon or Mexico. The people in this book, this play, this TV serial are not meant to represent any actual painters, cartographers, mechanics anywhere. The bigger your market, Montag, the less you handle controversy, remember that ! All the minor minor minorities with their navels to be kept clean. Authors, full of evil thoughts, lock up your typewriters. They did. Magazines become a nice blend of vanilla tapioca. Books, so the damned snobbish critics said, were dishwater. No wonder books stopped selling. (57) of competing media technologies (58). This idea is further emphasized in a later scene 
between Montag and Professor Faber that was added to the novel. After Montag presents Faber with the last remaining Bible, Faber once again admires the book as an object of quasi-religious veneration, but then he suddenly changes his mind and dismisses the significance of the book's material form :

It's not books you need, it's some of the things that once were in books.... The same infinite detail and awareness could be projected through the radios and televisors, but are not. No, no, it's not books at all you're looking for! Take it where you can find it, in old phonograph records, old motion pictures.... Books were only one type of receptacle where we stored a lot of things we were afraid we might forget. There is nothing magical in them at all. The magic is on in what books say, how they stitched the patches of the universe together into one garment for us. (82-83) 
resulted in the elimination of hierarchies of taste, which has produced a "homogenized" culture where everything is the same:

Mass Culture is a dynamic, revolutionary force, breaking down the old barriers of class, tradition, taste, and dissolving all cultural distinction.... It thus destroys all values, since value judgments imply discrimination. Mass Culture is very, very democratic : it absolutely refuses to discriminate against, or between, anything or anybody. All is grist to its mill, and all comes out finely ground indeed. (5) people and discrimination between things - is also illustrated in Bradbury's novel, which similarly presents democracy as a threat to culture. As Montag's boss explains : "We must all be alike. Not everyone born free and equal, as the Constitution says, but everyone made equal. Each man the image of every other; then all are happy, for there are no mountains to make them cower, to judge themselves against" (58). Like Macdonald, therefore, the novel seems to suggest that distinctions of taste depend on distinctions of class, and the elimination of one naturally results in the elimination of the other. The end result, according to Macdonald, is that the "intelligentsia" is "disintegrated," standards of taste sink to the level of the "most ignorant," and standards of morality sink to the level of the "most brutal and primitive members" of society (70) - a vision of the future that Bradbury's novel seems to endorse.

However, such a reading overlooks the inherent contradictions between the novel's critique of lowbrow culture and its critique of middlebrow culture. In other words, how can the novel condemn lowbrow culture while at the same time condemning the special interest groups that were waging a crusade against lowbrow culture? This contradiction can be resolved, I would argue, by considering Bradbury's novel in light of Leslie Fiedler's contribution to the mass culture debates on the 1950s. In his 1955 essay "The Middle Against Both Ends," Fiedler specifically addresses Wertham's attack on comic books and the moral panic over mass culture that had gripped the nation in the late 1940s and early 1950s. Unlike Macdonald, however, Fiedler argues that these attacks represent a concealed attack on high culture as well, as the critics of mass culture are attacking something that is also present in high culture - something that "moves all literature of worth" (423) - namely, sex and violence. By addressing these topics, mass culture and high culture both "touch on archetypal material: those shared figures of our lower minds more like the patterns of dream than fact" (420). Fiedler thus argues that "behind the opposition to vulgar literature, there is at work the same fear of the archetypal and the unconscious itself that motivated similar attacks on Elizabethan drama and on the eighteenth-century novel" (424). Fiedler thus describes the morality campaigns of the late 1940s and early 1950s as a "two-front class war: the readers of the slicks battling the subscribers to the "little reviews' and the consumers of pulps" (426). The "middlebrow" critic attacks high culture (as embodied in the "little reviews") because it "baffles his understanding," and he attacks mass culture (as embodied in the "pulps") because it "refuses to aspire to his level" (428). Fiedler thus concludes that "the fear of the vulgar is the obverse of the fear of excellence, and both are aspects of the fear of difference: symptoms of a drive for conformity on the level of the timid, sentimental, mindlessbodiless genteel" (428). In other words, middlebrow culture attempts to achieve a classless society by promoting social conformity through the elimination of hierarchies of taste.

Fiedler's basic insight - that lowbrow culture was perceived as a challenge to middlebrow conformity - is particularly useful for understanding the social context of Fahrenheit 451. 
While the story version would have appealed to middlebrow readers, who saw their own book burnings as a justifiable means of defending society from the corrupting influence of lowbrow culture, the novel version provides a more overt attack on middlebrow culture and its vision of a classless society. Instead of reinforcing the cultural authority of the literary elite, for example, the novel specifically describes the problem of social conformity as the result of a burgeoning middle class that was attempting to reinforce its own cultural hegemony by eliminating hierarchies of taste. In other words, the novel cannot simply be interpreted as elitist and anti-democratic because it explicitly argues for the preservation of multiple taste cultures, as emphasized in Faber's revised speech. Bradbury also clearly agreed with Fiedler that lowbrow culture was capable of doing many of the same things as highbrow culture, such as the possibility of challenging the status quo as described in his letter to the editors of Weird Fantasy, which helps to explain how he was able to reconcile his critique of mass media and his own participation in the entertainment industry. Bradbury's desire to preserve multiple taste cultures is most clearly illustrated by the many different forms in which the novel was published. While the hardcover and deluxe editions helped Bradbury to achieve a greater level of cultural prestige, the paperback and magazine editions also provided access to a mass audience. Rather than attempting to argue for the cultural legitimacy of science fiction by distancing the genre from its lowbrow origins, Bradbury thus took advantage of the new material forms that were available to science fiction in the early 1950s in order to cultivate the widest possible range of readerships and taste cultures, and the various material instantiations of the text clearly show that a democracy can support the existence of different cultural classes.

\section{BIBLIOGRAPHY}

Ashley, Mike. Transformations: The Story of the Science Fiction Magazines from 1950 to 1970. Liverpool : Liverpool University Press, 2005. Print.

Attebery, Brian. “The Magazine Era: 1926-1960.” The Cambridge Companion to Science Fiction. Ed. Edward James and Farah Mendlesohn. Cambridge: Cambridge University Press, 2003. 32-47. Print. Bradbury, Ray. Fahrenheit 451. New York: Del Rey, 1991. Print.

Bradbury, Ray. “The Fireman.” Galaxy 1.5 (February 1951): 4-61. Print.

Brier, Evan. A Novel Marketplace: Mass Culture, the Book Trade, and Postwar American Fiction.

Philadelphia : University of Pennsylvania Press, 2010. Print.

“Cosmic Correspondence." Weird Fantasy \#20 (July-August 1953). Print.

Crist, Judith. "Horror in the Nursery." Collier's March 27, 1948: 22-23+. Print.

DeVoto, Bernard. “Doom Beyond Jupiter.” Harper's Magazine 179 (September 1939): 445-448. Print.

Eller, Jonathan R. Becoming Ray Bradbury. Urbana: University of Illinois Press, 2011. Print. 
Fiedler, Leslie. "The Middle Against Both Ends." Collected Essays of Leslie Fiedler. 2 vols. New York: Stein \& Day, 1971. 2: 415-428. Print.

Hajdu, David. The Ten-Cent Plague: The Great Comic-Book Scare and How It Changed America. New York: Picador, 2009. Print.

Hansen, Thomas S. Classic Book Jackets: The Design Legacy of George Salter. New York: Princeton Architectural Press, 2005. Print.

Hemley, Cecil. "The Problem of the Paper-backs." Mass Culture: The Popular Arts in America. Ed. Benard Rosenberg and David Manning White. New York: Free Press, 1957. 141-146. Print.

Hoskinson, Kevin. “The Martian Chronicles and Fahrenheit 451 : Ray Bradbury's Cold War Novels.” Extrapolation 36.4 (1995): 345-359. Print.

Isherwood, Christopher. "Christopher Isherwood Reviews The Martian Chronicles.” Tomorrow 10.2 (1950): 56-58. Print.

Jones, Gerard. Men of Tomorrow: Geeks, Gangsters, and the Birth of the Comic Book. New York: Basic Books, 2004. Print.

Leavis, F. R. "Mass Civilization and Minority Culture." Cultural Theory and Popular Culture : A Reader . Ed. John Storey. London: Pearson, 2006. 12-19. Print.

Leavis, F. R., and Denys Thompson. Culture and Environment: The Training of Critical Awareness. London: Chatto \& Windus, 1933. Print.

Macdonald, Dwight. “A Theory of Mass Culture.” Diogenes 1.3 (1953): 1-17. Print.

McGiveron, Rafeeq O. "What 'Carried the Trick'? Mass Exploitation and the Decline of Thought in Ray Bradbury's Fahrenheit 451.” Extrapolation 37.3 (1996): 245-256. Print.

Mogen, David. Ray Bradbury. Boston: Twayne, 1986. Print.

"Poet of the Pulps." Time 61.12 (March 23, 1953): 116. Print.

Russell, Ray. Preface. The Playboy Book of Science Fiction and Fantasy. Ed. Ray Russell. Chicago: Playboy Press, 1966. vii. Print.

Weller, Sam. “Ray Bradbury: The Art of Fiction No. 203.” Paris Review 192 (2010). Web.

Wertham, Fredric. “The Comics...Very Funny!” Saturday Review of Literature May 29, 1948: 6-7, 27-29. Print.

Wright, Bradford. Comic Book Nation: The Transformation of Youth Culture in America. Baltimore: Johns Hopkins University Press, 2001. Print.

Zipes, Jack. "Mass Degradation of Humanity and Massive Contradictions in Bradbury's Vision of America in Fahrenheit 451." No Place Else: Explorations in Utopian and Dystopian Fiction. Carbondale: Southern Illinois University Press, 1983. 182-198. Print. 